\title{
PERANAN MAKROFAG PADA PROLIFERASI, DIFERENSIASI DAN APOPTOSIS PADA PROSES HEMATOPOISIS (PENELITIAN PADA LIMPA JANIN TIKUS DAN ASPIRAT SUMSUM TULANG MANUSIA)
}

\author{
(THE ROLE OF MACROPHAGE ON PROLIFERATION, \\ DIFFERENTIATION AND APOPTOSIS DURING HAEMATOPOIESIS) \\ (STUDY ON FETAL RAT SPLEEN AND HUMAN MARROW ASPIRATE)
}

\author{
Edi Widjajanto \\ Bagian Patologi Klinik Fakultas Kedokteran Unibraw /RSU dr. Saiful Anwar Malang
}

\begin{abstract}
Macrophage stimulates growth of surrounding cells by various cytokines and growth factors synthesized and eliminate apoptotic cells by its phagocytes activity. This study was to evaluate the evidence of macrophage as regulator cells during haematopoiesis. Haematopoietic activity assessed microscopically by proportion of various haematopoietic blood cells to total nucleated blood cells on imprint preparation of fetal ratus (Wistar) spleen and human marrow aspirate, after Wright's stain coloration. Fetal ratus spleen and human marrow aspirate were used to evaluate macrophage as a stimulator cell and suppressor cell respectively. During prenatal period, the proportion of macrophage increased at $14^{\text {th }}$ days $(1.3 \pm$ $0.9 \%), 16^{\text {th }}$ days $(7.6 \pm 1.8 \%), 18^{\text {th }}$ days $(12.9 \pm 2.8 \%)$ and $20^{\text {th }}$ days prenatal gestation periods $(14.1 \pm 3.1 \%)$. This macrophage increment was associated with the increase of other blood cells, except the proportion of lymphoid cell which decreased. During postnatal period the macrophage proportion decreased (11.0 $\pm 1.7 \%)$, and other blood cells proportion continuously increased except lymphoid cells which decreased. Many haematopoietic islands representing active haematopoietic process were found at $14^{\text {th }}$ days of fetal rat spleen. Macrophage in human hypocellular marrow $(n=$ 9) increased and it exceed other blood cells proportion $(29 \%, p<0.001)$ and contained phagocytosed apoptotic bodies. This study concludes that high macrophage regulates haematopoiesis when it was proportionally low and regulate haematopoiesis when it was proportionally high.
\end{abstract}

Keywords: Macrophage, Apoptosis, Haematopoiesis

\section{PENDAHULUAN}

Makrofag merupakan sel yang tersebar luas di berbagai jaringan, merupakan fagosit, antigen processing dan antigen presenting cells (APC) serta merupakan sel yang menghasilkan berbagai macam mediator. Berbagai jenis mediator yang disintesis oleh makrofag antara lain adalah (i) growth factors; SCF (stem cell factor), GCSF (granulocyt colony stimulating factor), GMCSF (granulocyt macrophage colony stimulating factor), Epo (eritropoietin), FGF (fibroblast growth factor), PAF (platelet activating factor), (ii) interleukin; IL-1, IL-2, IL-4, IL-6, IL-8, IL-10, IL-12, (iii) protease dan protease inhibitor, (iv) interferon (IFN); IFN- $\alpha,-\beta,-\gamma$, (v) TNF- $\alpha$ (tumor necrozing factor), TGF- $\beta$ (transforming growth factor), (vi) radikal bebas; ROS (reactive oxygen species), RNS (reactive nitrogen species) $(1,2,3)$. Berbagai mediator tersebut berkaitan dengan berbagai aktivitas biologi dari makrofag, antara lain (i) antigen processing dan presenting cells, (ii) pagositosis, (iii) antimikrobial, (iv) anti tumor, (v) angiogenesis, (vi)

Jurnal Kedokteran Brawijaya, Vol. XXI, No.1, April 2005 Korespondensi: Edi Widjajanto; Laboratorium Patologi Klinik Fakultas Kedokteran Unibraw, Jl. Veteran Malang 65145. coagulant initiation, (vii) iron metabiolism, (viii) arachidonate metablism $(4,5,6)$.

Penelitian ini merupakan studi untuk mempelajari dinamika makrofag dalam proses hematopoisis berkaitan dengan peran makrofag sebagai pemacu hematopoisis dan peran makrofag sebagai penghambat hematopoisis, apakah perbedaan proporsi makrofag berkaitan dengan stimulasi atau inhibisi hematopoisis.

\section{METODE}

Penelitian menggunakan limpa janin tikus dan aspirat sumsum tulang manusia sebagai bahan pemeriksaan hematologik untuk pemeriksaan rutin terkait penatalaksanaan penyakit hematologik. Secara skematis metode penelitian ini dituangkan pada bagan Gambar 1.

\section{Cara kerja}

Sediaan tekan segera diwarnai dengan pewarnaan My Grunwald-Giemsa (MGG) (7). Sediaan iris diwarnai dengan pewarnaan hematoksilin eosin $(\mathrm{HE})$ menurut Luna (1968) (8). Untuk beberapa kehamilan dan neonatus dilakukan pewarnaan esterase nonspesifik dan spesifik, pewarnaan toluidin biru, esterase asetilkholin dan peroksidase Lephene $(9,10,11,12,13)$. 
Untuk membedakan antara sel parenkhim limpa dengan sel darah (sel darah) dipergunakan pedoman morfologi menurut Djaldeti et al (1972), Wintroube (1981) dan Lila (1983) sebagai berikut $(14,15,16)$.

1. Sel parenkhim limpa. Sel parenkhim limpa merupakan sel berukuran besar berbentuk oval atau bulat. Sitoplasmanya sedikit dan berwarna keunguan, intinya besar berbentuk bulat atau oval dengan susunan retikulum yang halus, kepekatan warna inti lebih tipis dibanding sel darah.

2. Sel eritroid. Sel eritroid berukuran kecil sampai sedang (12 - 17 um), intinya berwarna gelap dengan kromatin yang kasar, sitoplasmanya bersifat polikromatofil atau asidofil.

3. Netrofil, eosinofil dan basofil. Sel ini mudah dkenal dari bentuk intinya dan granulanya yang spesifik.

4. Megakaryosit. Megakaryosit mudah dikenal karena merupakan sel yang besar ( $35-160$ um), bentuk tidak teratur, sitoplasmanya mengandung granula halus berwarna merah-ungu.

5. Monosit-makrofag. Maktofag berukuran sedang sampai besar (15 - $80 \mathrm{um})$, sering dalam bentuk ameboid, intinya bulat atau lonjong.

6. Limfosit. Limfosit merupakan sel berukuran kecil sampai sedang (7 - 18 um), intinya hampir memenuhi sel dengan kromatin yang padat dan berwarna gelap.

7. Mastosit. Mastosit mudah dikenal karena sifat granulanya yang metakhromatik, ukurannya sangat bervariasi dari kecil sampai besar.

8. Sel limfoid. Sel limfoid adalahsel yang tidak dapat digolongkan ke dalam salah satu golongan tersebut di atas dan morfologinya menyerupai morfologi limfosit.

Aspirat sumsum tulang didapatkan melalui aspirasi sumsum tulang menurut prosedur standar dan dipilih tempat aspirasi di spina ischiadica superior posterior (SIPS) atau di crista iliaca. Aspirasi dilakukan menggunakan jarum aspirasi Jamsidi dan iisap aspirat sebanyak $1-2 \mathrm{ml}$, aspirat segera ditampung di botol penampung yang telah diisi antikoagulan EDTA sebanyak 1 - $2 \mathrm{mg}$. Dari aspirat dibuat sediaan tekan, dihitung jumlah sel sumsum tulangnya (nucleated cells) dan proporsi sel darahnya (marrow gram).

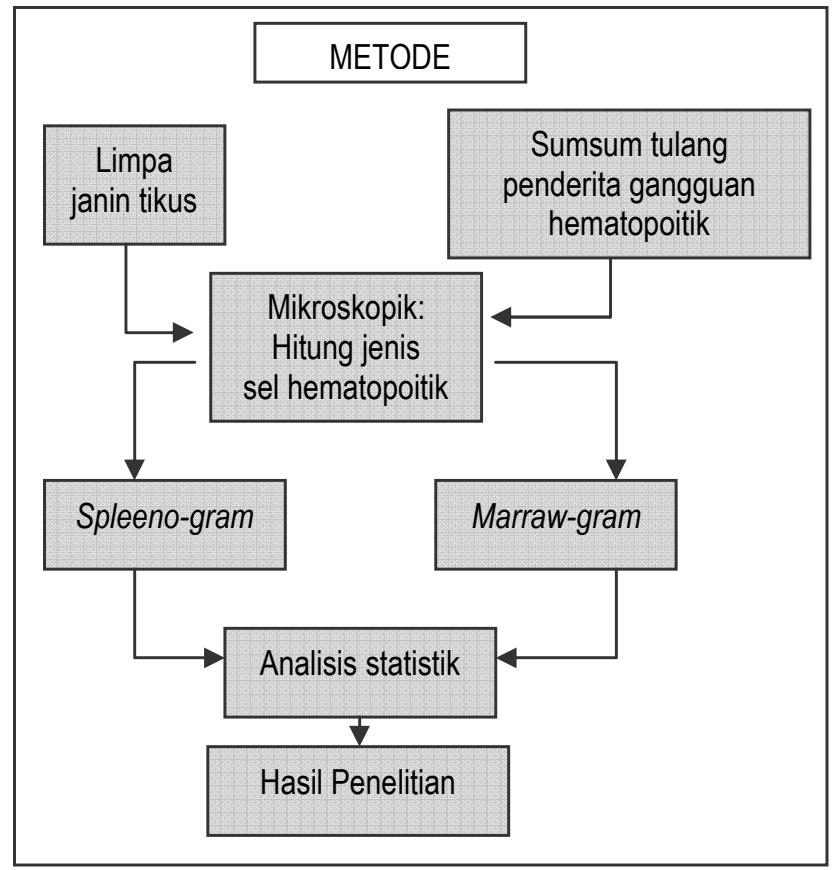

Gambar 1. Bagan Metode Penelitian

Beberapa hal penting berkaitan dengan pemeriksaan sel apoptotik adalah sebagai berikut.

1. Pada penelitian ini digunakan pewarnaan Wrigt's stain untuk identifikasi sel limfoid yang mengalami apoptosis dan berbagai jenis sel hematopoitik lainnya.

2. Identifikasi sel apoptotik berdasarkan kriteria morfologik secara mikroskopik yang merupakan metode standar, selain itu dengan cara ini dapat dikenal dan dihitung proporsi sel limfoid apoptotik terhadap sel hematopoitik lainnya $(17,18,19)$.

3. Jumlah sel limfoid apoptotik atau sel apoptotik ditandai oleh kondensasi kromatin, sel shrinkage serta berbagai tanda morfologik, hasilnya dinyatakan dalam (\%) (17).

4. Skematik sel yang mengalami apoptosis tampak pada Gambar 3 (17).

\section{Analisis hasil penelitian}

Setelah data dikumpulkan dalam tabel menurut kelompok umur, dilanjutkan dengan analisis statistik. Hasil analisis dicantumkan dalam tabel dan grafik. Hasil pengamatan morfologik disajikan dalam beberapa foto. Untuk menguji kemaknaan perbedaan hasl digunakan analisis varian (Anova). 


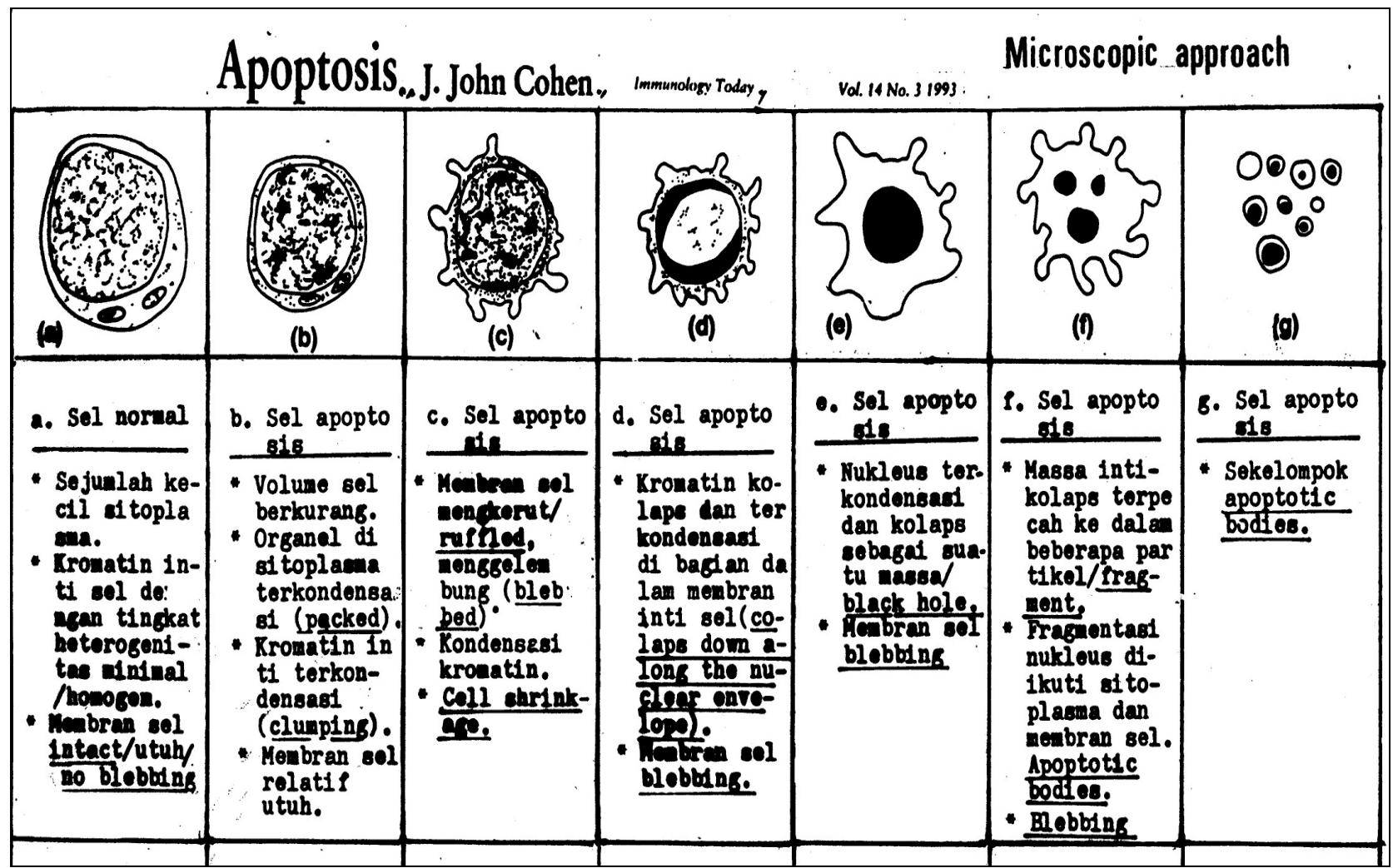

Gambar 2. Skematis Sel yang Mengalami Apoptosis.

Pengamatan mikroskopis dari limfosit yang mengalami berbagai tahap apoptosis, mulai dari derajad ringan (awal) sampai lanjut (terbentuknya apoptotic bodies, g) (17)

\section{HASIL PENELITIAN}

Hasil penelitian disajikan dalam bentuk foto, tabel dan grafik berkaitan dengan morfologi sel darah serta jumlahnya.

Tabel 1 menunjukkan perubahan yang bermakna pada proporsi eosinofil, limfosit, monosit-makrofag, sel eritroid, sel limfoid dan megakaryosit selama masa janin dan neonatus $(p<0,001)$, serta perubahan proporsi pada netrofil dan mastosit $(p<0,05)$. Perubahan jumlah tersebut dapat bersifat naik maupun turun (sel limfpoid) sebagaimana yang terlihat pada tabel.

Tabel 1. Hitung Jenis Sel Darah Dalam Limpa Janin Tikus dan Neonatus

\begin{tabular}{|c|c|c|c|c|c|c|}
\hline \multirow[t]{2}{*}{ Jenis sel } & \multirow{2}{*}{$\begin{array}{c}X \\
\text { SD (\%) }\end{array}$} & \multicolumn{4}{|c|}{ Umur janin (hari) } & \multirow{2}{*}{$\begin{array}{c}\text { Neonatus (jam) } \\
0-24\end{array}$} \\
\hline & & 14 & 16 & 18 & 20 & \\
\hline \multirow[t]{2}{*}{ Eosinofil } & $\mathrm{X}$ & & 0,3 & 2,3 & 2,8 & 1,6 \\
\hline & SD & & 0,8 & 1,1 & 0,8 & 0,9 \\
\hline \multirow[t]{2}{*}{ Netrofil } & $\mathrm{X}$ & & 6,3 & 35,3 & 21,1 & 14,5 \\
\hline & SD & & 3,1 & 13,0 & 4,7 & 3,5 \\
\hline \multirow[t]{2}{*}{ Limfosit } & $\mathrm{x}$ & & 3,0 & 27,1 & 38,9 & 29,0 \\
\hline & SD & & 1,8 & 6,2 & 7,7 & 6,7 \\
\hline \multirow[t]{2}{*}{ Monosit-makrofag } & $\mathrm{X}$ & 1,3 & 7,6 & 12,9 & 14,1 & 11,0 \\
\hline & SD & 1,9 & 1,8 & 2,8 & 3,1 & 1,7 \\
\hline \multirow[t]{2}{*}{ Sel eritroid } & $\mathrm{X}$ & 14,0 & 14,7 & 16,9 & 18,6 & 39,8 \\
\hline & SD & 1,9 & 2,4 & 9,7 & 5,6 & 8,2 \\
\hline \multirow[t]{2}{*}{ Sel limfoid } & $\mathrm{X}$ & 84,6 & 67,3 & 2,3 & 1,6 & 1,0 \\
\hline & SD & 3,3 & 6,6 & 1,3 & 0,4 & 0,7 \\
\hline \multirow[t]{2}{*}{ Mastosit } & $\mathrm{X}$ & & 1,1 & 3,2 & 2,9 & 1,9 \\
\hline & SD & & 1,2 & 1,9 & 1,6 & 0,9 \\
\hline \multirow[t]{2}{*}{ megakaryosit } & $\mathrm{X}$ & & & & 0,1 & 0,9 \\
\hline & SD & & & & 0,2 & 0,5 \\
\hline
\end{tabular}




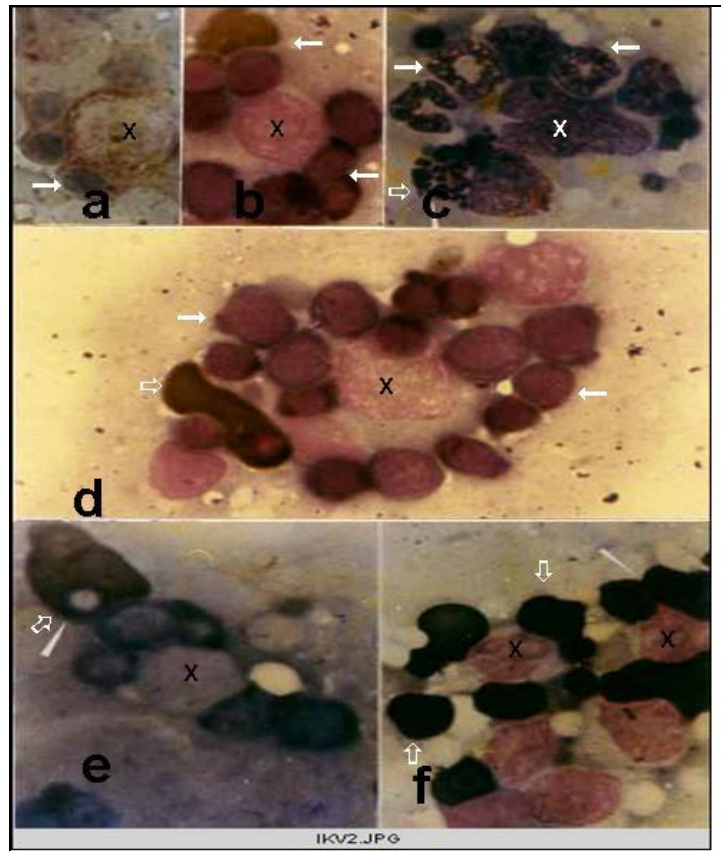

\section{A. Makrofag}

menyusui sel hematopoitik (feeder cells) Makrofag yang memulai hematopoisis KONAS IV PDS

PATKLIN 2001, Bdg

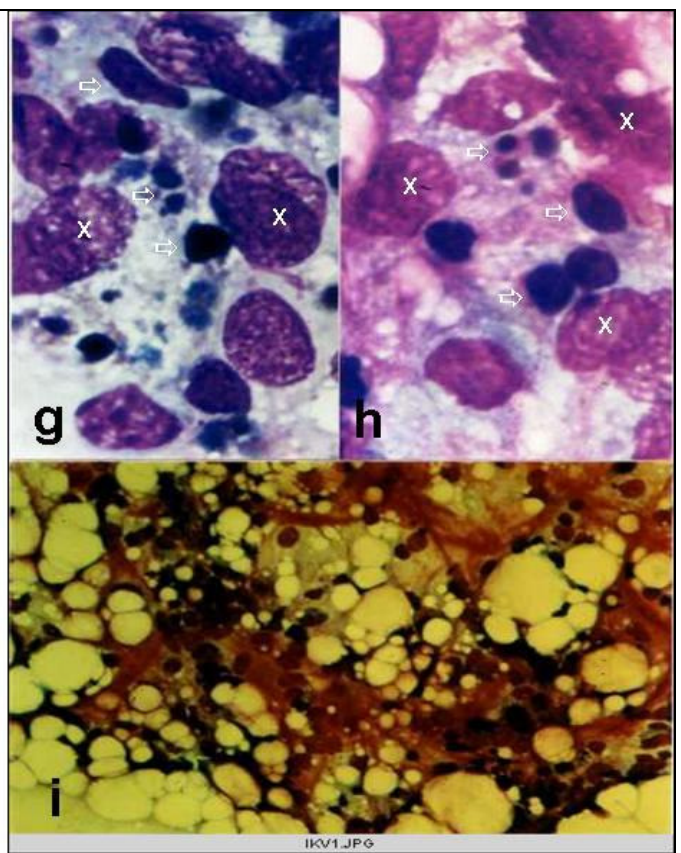

\section{B. Makrofag}

memicu apoptosis (grave celis) Makrodag yang mengakhiri hematopoisis

\section{Keterangan:}

\section{Gambar 3. Makrofag dan Dinamika Hematopoisis}

A. Makrofag sebagai feeder cell, merupakan sel yang 'menyusui' sel darah yang mengelilinginya untuk mendapatkan berbagai grwoth factor yang disintesis oleh makrofag, makrofag memulai proses fagositosis, makrofag memacu hematopoisis.

a. Immunoblastic island (pulau imunoblas), makrofag ( $\mathrm{x}$ ) sel berinti dengan sitolplasma tampak coklat dikelilingi limfoblas $(\rightarrow)$, makrofag memacu limfopoisis (Pewarnaan Esterase, $1000 \mathrm{x}$ ).

b. Monoblastic island (pulau monoblas), makrofag (x) dikelilingi monoblas $(\rightarrow)$, makrofag memacu monopoisis (Pewarnaan Wrigt's, $1000 \mathrm{x}$ ).

c. Granulopoietic island (pulau granulositik), makrofag (x) dikelilingi berbagai jenis granulosit:; netrofil segmen dan stab $(\rightarrow)$, serta mastosit $(\Rightarrow)$ (Pewarnaan Wrigt's, $1000 \mathrm{x}$ ).

d. Monoblastic island (pulau monoblas), makrofag ( $\mathrm{x}$ ) dikelilingi monoblas $(\rightarrow)$ tampak juga eritrosit berinti yang merupakan eritrosit matur $(\Rightarrow)$ hasil eritropoisis stadium yolk sac yang migrasi ke limpa janin. Pewarnaan lephen peroksidase menyebabkan eritrosit berwarna hitam-coklat, makrofag memacu monopoisis (Pewarnaan Lephene peroksidase, $1000 \mathrm{x}$ ).

e. Eritroblastic island (pulau eritroblas), makrofag ( $\mathrm{x}$ ) dikelilingi eritroblas yang tampak berwarna hitam-coklat (spesifik untuk kandungan Hemoglobin) pada pewarnaan lephen peroksidase, terdapat juga eritrosit berinti stadium yolk sac ( $\Rightarrow$ ) (lephene peroksidase, $1000 \mathrm{x}$ ).

f. Eritroblastic island (pulau eritroblas), makrofag (x) dikelilingi eritrsit yang tampak berwarna hitam-coklat (spesifik untuk kandungan Hemoglobin) pada pewarnaan lephen peroksidase, eritrosit stadium limpa janin tidak berinti $(\Longleftrightarrow)$ ) sebagaimana eritrosit berinti stadium yolk sac (lephene peroksidase, $1000 \mathrm{x}$ ).

B. Makrofag sebagai fagosit terhadap sel yang telah mengalami proses apoptosis, makrofag sebagai "kuburan" sel yang mati (grave cells), makrofag mengakhiri hematopoisis, sediaan diambil dari aspirat sumsum tulang hiposeluler penderita anemia aplastik.

g. Kumpulan makrofag $(\mathrm{x})$ memfagositosis sel yang telah mengalami apoptosis, apoptotic bodies $(\Rightarrow)$, tampak pulau makrofag yang aktif (multinucleated macrophage) mengelilingi-memfagositosis apoptotic bodies. (Pewarnaan Wrigt's, $1000 \mathrm{x})$.

h. Kumpulan makrofag $(x)$ memfagositosis apoptotic bodies $(\Rightarrow)$ (Pewarnaan Wrigt's).

i. Sumsum tulang hiposeluler dari penderita anemia aplastik dengan peningkatan proses apoptosis dari sel limfoid, tampak marrow particle kosong, tidak terisi oleh sel hematopoitik (Pewarnaan Wrigt,s $1000 \mathrm{x}$ ). 


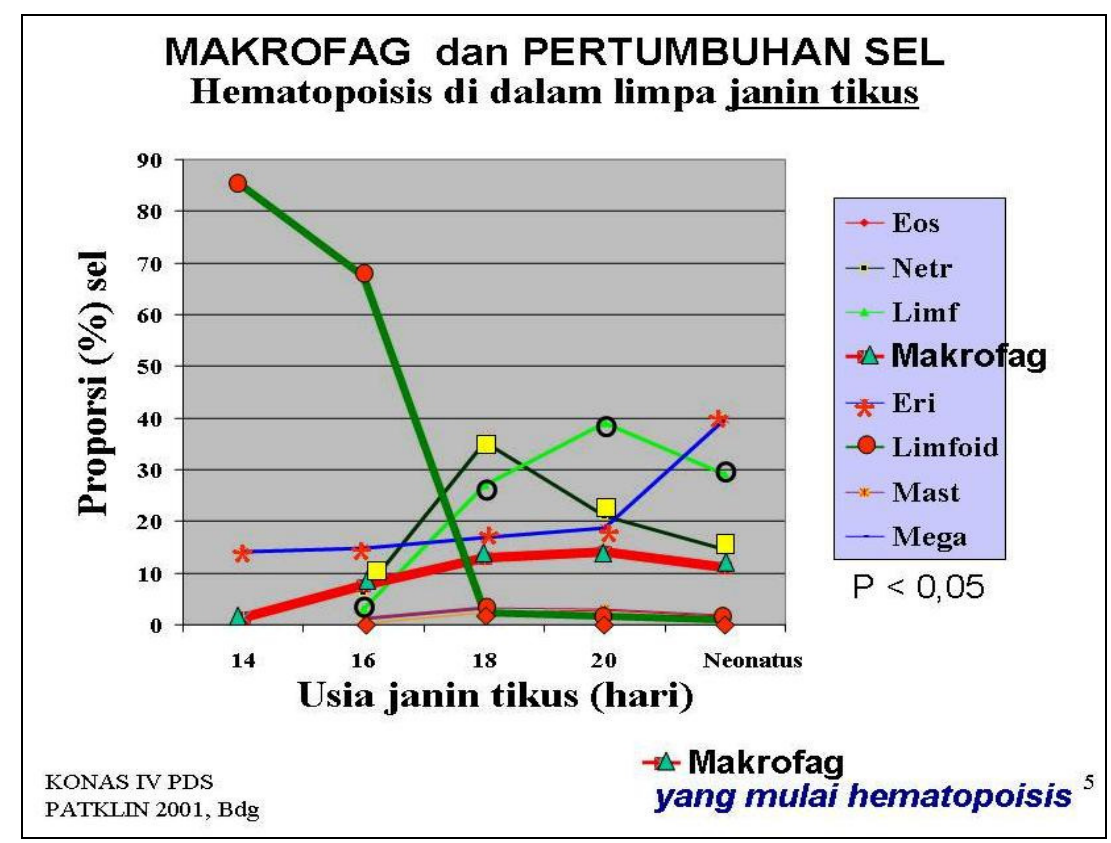

Gambar 4. Makrofag memacu hematopoisis di dalam limpa janin tikus

Berbagai fluktuasi peningkatan dan penurunan hematopoisis diuraikan di dalam teks narasi. Pada dasarnya tampak bahwa peningkatan proporsi makrofag disertai dengan peningkatan berbagai sel darah lainnya, kecuali sel limfoid mengalami penurunan proporsi.

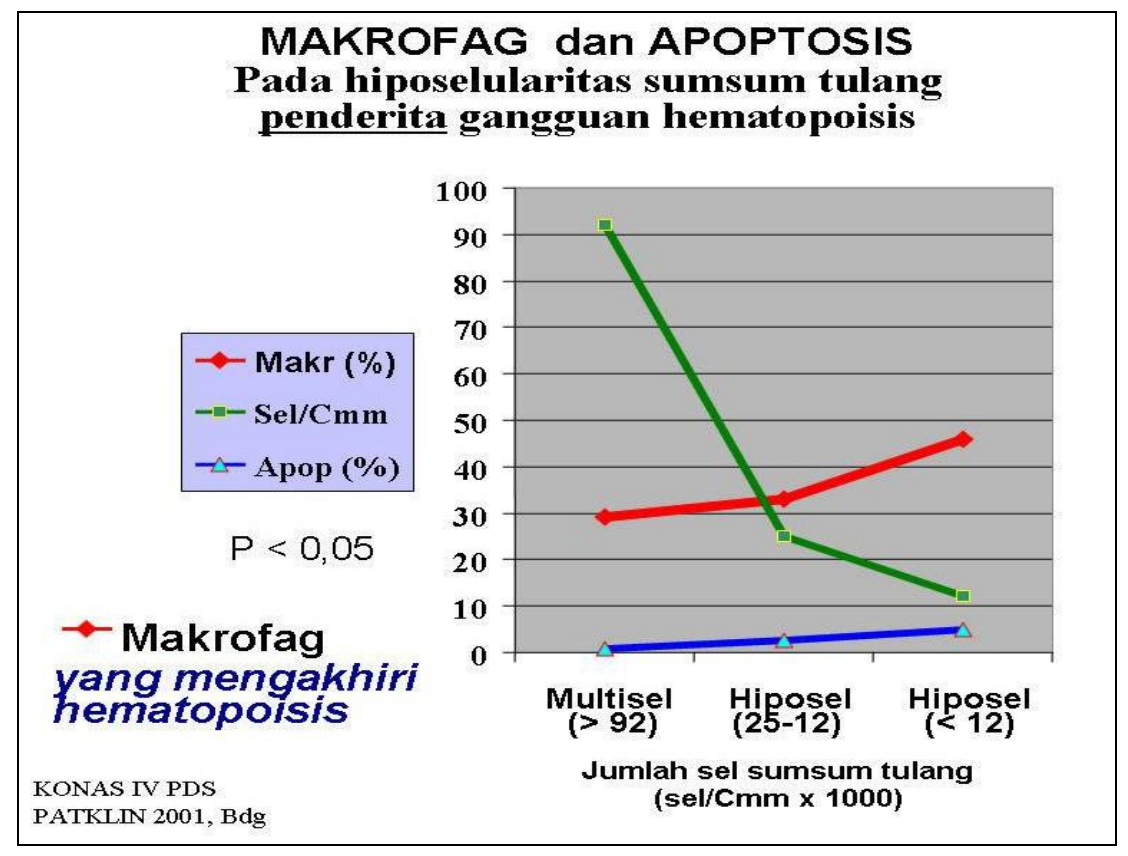

Gambar 5. Makrofag dan proses apoptosis

Proporsi sel sumsum tulang, makrofag dan mastosit dari sediaan aspirat sumsum tulang berbagai karakteristik sumsum tulang (multiseluler, hiposeluler ringan dan hiposeluler berat). Peningkatan proporsi makrofag berkaitan sejalan dengan peningkatan proprsi sel yang mengalami apoptosis, tetapi berbanding terbalik dengan proporsi sel hematopoisis atau selularitas sumsum tulang. 


\section{DISKUSI}

Dari uji Anova (Tabel 1) tampak bahwa perubahan yang terjadi pada eosinofil, limfosit, monosit-makrofag, sel eritroid, sel limfoid dan megakaryosit selama masa janin dan neonatus yang diteliti sangat bermakna $(p<0,001)$. Sedangkan netrofil dan mastosit berubah bermakna $(p<$ 0,05).

Selain itu dari hasil penelitian juga tampak bahwa monopoisis dan eritropoisis mendahului hematopoisis yang lain. Tampaknya mulai kehamilan 14 hari sampai kehamilan 18 hari proses proliferasi melebihi proses diferensiasi, kemudian proses diferensiasi mengatasi proliferasi. Hal ini tampak dari jumlah perbandingan sel limfoid dengan sel yang telah berdiferensiasi, proporsi jumlah sel limfoid makin turun sedangkan padaumumnya proporsi sel yang telah berdiferensiasi makin naik proporsinya.

Grafik (Gambar 4) dinamika proporsi berbagai sel darah menunjukkan bahwa monopoisis telah terjadi pada kehamilan 14 hari, beberapa monoblas dan promonosit tampak di antara sel parensim limpa. Bermula dengan jumlah sekitar satu persen selanjutnya pada umur 16 dan 18 hari meningkat sangat bermakna $(p<0,01)$ sehingga jumlahnya mencapai 12 persen. Jumlah monosit-makrofag mencapai puncaknya pada kehamilan 20 hari, tetapi dibandingkan kehamilan 18 hari peningkatan jumlah tersebut tidak bermakna $(p>0,05)$. Pada sediaan tekan limpa janin yang berumur 18 hari tampak kelompokkelompok monosit-makrofag yang tercampur dengan sel darah yang lain. Dibanding dengan janin umur 20 hari jumlah monosit-makrofag pada neonatus turun bermakna ( $p$ $<0,05)$.

Eritropoisis (Gambar 4) mulai pada umur 14 hari ditandai dengan kelompok-kelompok sel eritroid yang mengelilingi makrofag (eritroid island atau pulau eritroid) di antara sel parensim limpa (Gambar 2). Peningkatan eritropoisis pada usia kehamilan 16, 18 dan 20 hari tidak bermakna $(p>0,05)$, peningkatan bermakna baru terjadi antara janin 20 hari dengan neonatus $(p<0,05)$. Sejak usia kehamilan 18 hari dan seterusnya sampai neonatus dapat dijumpai kelompok-kelompok sel eritroid yang membentuk pulau eritroid bersama monosit-makrofag.

Granulopoisis (Gambar 4) telah terjadi pada janin umur 16 hari. Sel granuloid yang pertama dapat diamati adalah promelosit dan melosit, baik dari deret netrofil maupun eosinofil. Pada janin 18 hari terjadi peningkatan netrofil $(p<0,01)$, selanjutnya pada umur 20 hari terjadi penurunan $(p<0,05)$. Eosinopoisis dari janin 16 hari meningkat pada hari ke $18(p<0,01)$, dan mencapai puncak peningkatan pada hari ke 18 dan 20 umur janin, selanjutnya turun pada neonatus $(p<0,05)$. Mastosit di dalam limpa tampak pada janin umur 16 hari, pada janin 18 hari terjadi peningkatan mastopoisis $(p<0,01)$ dan turun pada hari ke 20 dan neonatus $(p<0,05)$. Berbagai jenis granulopoisis juga tampak sebagai granulopoietic island atau pulau granulosit (Gambar 3-A).

Limfopoisis (Gambar 4) mulai tampak pada janin umur 16 hari, pada janin 18 dan 20 hari meningkat $(p<$ $0,01)$, dan turun pada neonatus $(p<0,05)$. Peningkatan limfopoisis disertai peningkatan immunoblastic island atau pulau imunoblas sebagai yang tampak pada Gambar 3-A.

Megakaryopoisis (Gambar 4) ditandai dengan adanya megakaryosit pada janin berumur 20 hari, megakarypoisis meningkat pada neonatus $(p<0,01)$.

Sel limfoid (Gambar 4) merupakan sel yang terbesar jumlahnya pada limpa janin berumur 14 hari. Makin tua umur janin jumlah sel limfoid makin kurang, penurunan sangat bermakna $(p<0,001)$ berturut-turut terjadi pada janin umur 16 dan 18 hari, pada janin 20 hari jumlahnya relatif tetap $(p>0,05)$, pada neonatus jumlah sel limfoid jumlahnya turun $(p<0,05)$.

Dari berbagai temuan hematopoisis di dalam limpa janin tikus tersebut tampak bahwa peningkatan proporsi jumlah makrofag (monopoisis) disertai dengan peningkatan eritropoisis, granulopoisis, megakaryopoisis dan limfopoisis, serta peningkatan berbagai pulau hematopoitik. Hal ini mengisyaratkan bahwa makrofag merupakan sel yang memacu hematopoisis. Selain itu juga tampak bahwa peningkatan aktifitas monosit-makrofag dan berbagai jenis hematopoisis disertai dengan penurunan jumlah sel limfoid. Sebagaimana telah diketahui secara mikroskopis morfologi haematopoietic stem cells tampak menyerupai limfosit dengan ukuran sel yang lebih kecil dan inti sel tampak lebih padat. Peningkatan jumlah makrofag disertai penurunan jumlah sel limfoid mengisyaratkan bahwa makrofag memacu diferensiasi sel limfoid (haematopiietic stem cell) menjadi berbagai jenis sel darah yang lain (eritrosit, granulosit, limfosit dan monosit-makrofag).

Gambar 5 menunjukkan bahwa peningkatan proporsi jumlah makrofag $(p<0,05)$ dari sumsum tulang hiper(multiseluler), hiposeluler ringan dan hiposeluler berat disertai dengan peningkatan proporsi jumlah sel sumsum tulang yang mengalami apoptosis $(p<0,05)$. Kedua hal tersebut disertai dengan penurunan jumlah absolut sel sumsum tulang $(p<0,001)$. Sejalan dengan hal tersebut terjadi pula peningkatan makrofag dalam proses fagositosis sel yang mengalami apoptosis, sebagaimana yang tampak pada Gambar 3-B. Hal tersebut di atas mengisyaratkan bahwa peningkatan proporsi makrofag memacu proses apoptosis dan berkaitan dengan hiposelularitas sumsum tulang.

Dari Gambar 4 dan Gambar 5 tampak bahwa proporsi makrofag dalam jumlah kecil $(<12 \%)$ bersifat merangsang pertumuhan sel darah, tetapi pada proporsi yang lebih tinggi (> $15-40 \%$ ) makrofag bersifat menghambat hematopoisis. Pada Gambar 4 tampak bahwa peningkatan proporsi makrofag secara berangsur-angsur 
sejak kehamilan 14 hari sampai kehamilan $18-20$ hari (makrofag $12 \%$ ), disertai peningkatan proporsi berbagai jenis sel darah (eritropoisis, granulopoisis dan megakaryopoisis). Selanjutnya setelah itu terjadi penurunan baik pada proporsi makrofag maupun berbagai sel darah yang lain. Pada Gambar 5 tampak bahwa proporsi makrofag sebesar $30 \%$ dan peningkatan proporsi selanjutnya disertai dengan penghambatan pertumbuhan sel darah sebagaimana yang ditunjukkan oleh penurunan jumla sel sumsum tulang, dan peningkatan apoptosis.

Bukti in vitro dan in vivo berikut menunjukkan bahwa efek stimulasi dan inhibisi makrofag tesebut dapat terjadi pada proses hematopoisis. Kurland et al (1978) menunjukkan bahwa penambahan monosit-makrofag meningkatkan pertumbuhan koloni granulosit-makrofag (1). Hal serupa juga terjadi pada pertumbuhan koloni eritroid. Penambahan sampai proporsi $15 \%$ bersifat merangsang, tetapi apabila penambahan nya diteruskan sampai menapai $40 \%$ atau lebih pertumbuhan koloni eritroid berhenti dan akhirnya mati (20). Secara in vivo peningkatan proporsi makrofag di dalam limpa janin tikus sampai $12,5 \%$ bersifat merangsang, tetapi pada peningkatan sampai mencapai 15 $\%$ terjadi hambatan pertumbuhan berbagai sel hematopoitik, kecuali sel eritroid dan megakaryosit (Gambar 4).

Makrofag mensintesis faktor pertumbuhan (misalnya growth factor, colony stimulating factor, GM-CSF) serta inhibitor pertumbuhan sel (misalnya TNF, prostaglandin (PGE-1, PGE-2). Pada kultur granulosit-makrofag pengaruh granulopoitin (GM-CSF) mula-mula lebih besar dibanding pengaruh prostaglandin. Dengan bertambah besarnya koloni granulosit-makrofag pengaruh inhibisi prostaglanding menjadi lebih kuat dan menghambat pertumbuhan koloni granulosit-makrofag $(1,3)$. Secara in vitro ditunjukkan bahwa jumlah inhibitor (TNF-a, macrophage inhibitory protein-1- $\alpha$, IFN- $\gamma$ ) yang disintesis oleh monosit-makrofag orang normal. Sintesis faktor pertumbuhan (IL-3, GM-CSF, SCF) sama dengan monosit-makrofag dari orang normal. Jadi pada anemia aplastik terjadi peningkatan kadar inhibitory mediators yang berkaitan dengan hiperaktifitas makrofag (5).

Hiposeluraitas sumsum tulang melalui proses imun yaitu limfosit $T$ sitotoksik, cytotoxic $T$ lymphocyte (CTL)
(2,21). Menurut Melehorst et al. (1997) pada anemia aplastik terdapat subtipe limfosit $T$ sitotoksik yang mengalami mutasi sehingga bersifat otoreaktif dan meningkatkan kematian sel sumsum tulang (sel induk hemopoisis) melalui apoptosis (22). Pada makrofag juga dikenal ada beberapa macam tipe misalnya sel kupfer, osteoclast dan mikroglia, masing-masing merupakan makrofag jaringan (tissue macrophage) yang terdapat di hati, tulang dan sistim syaraf. Apakah peningkatan jumlah makrofag yang diikuti oleh terjadinya hiposelularitas sumsum tulang pada penelitian sekarang juga berdasar pada hiperaktifitas makrofag yang bersifat otoreaktif. Hal ini belum dapat dijelaskan melalui penelitian sekarang.

\section{KESIMPULAN DAN SARAN}

Dari berbagai uraian di atas dapat disimpulkan beberapa hal sebagai berikut.

1. Makrofag merupakan sel yang berperan aktif dalam proses hematopoisis.

2. Dalam jumlah proporsi yang kecil makrofag merupakan sel yang menstimulasi pertumbuhan koloni hematopoisis.

3. Dalam jumlah proporsi yang besar makrofag bersifat menghambat pertumbuhan hematopoisis.

4. Stimulasi hematopoisis oleh makrofag diduga kuat melalui berbagai growth factor yang disintesis oleh makrofag.

5. Inhibisi hematopoisis melalui proses apoptosis dan diduga kuat melalui mediator inhibitor atau mediator stimulator untuk apoptosis.

Beberapa saran yang muncul berkaitan dengan hasil penelitian ini adalah sebagai berikut.

1. Identifikasi secara spesifik berbagai mediator baik yang terlibat dalam proses stimulasi maupun inhibisi proses hematopoisis, serta yang terlibat dalam proses apoptosis.

2. Penelitian yang berkaitan dengan pembuktian bahwa hiperaktifitas makrofag pada sumsum tulang hiposeluler sebagimana yang terjadi pada anemia aplstik berkaitan dengan otoreaktif dari makrofag terhapap sel darah di dalam sumsum tulang.

\section{DAFTAR KEPUSTAKAAN}

1. Kurland JI, Bockman RS, Broxmeyer HE. Limitation of Excessive Myelopoiesis by The Intrinsic Modulation of Macrophage Derived Prostaglandine E. Science. 1978; 199: 552 - 535.

2. Young NS, Maciejewsky J. The Pathophysiology of Acquired Aplastic Anemia. The New England Journal of Medicine 1997; 336: 1365 - 1372.

3. Weinberg JB. Mononuclear phagocytes. In (Lee GR, Foerster J, Luckens J, Parasvekas F, Greer JP, Rodgers GM, eds). Wintroub's Clinical Haematology. Philadelphia: Lippincot Williams and Wilkins; 1998; $377-414$.

4. Williams DE. Optimizing The Effectiveness of Haematopoietic Growth Factors. Journal of clinical immunology 1994; 14: $327-414$. 
5. Hsu HC, Tsai WH, Chen LY, Hsu ML, Inf TKB, Ho CH, Lin CK, Wang SY. Production of Hamatopoetic Regulatory Cytokines by Peripheral Blood Mononuclear Cells in Patients with Aplastic Anemia. Exprimental Hematology 1996; 24: $31-36$.

6. Abbas AK, Lichtman AH, Prober JS. Cellular and Molecullar Immunology, $4^{\text {th }}$ edition. Philadelphia: WB Saunders Co.; 2000; 424-444.

7. Hayoe FGJ, Flman RJ. A Colour Atlas of Haematological Cytology, $2^{\text {nd }}$ Ed. London: Wolfe Medical Publication Ltd; 1982; 233.

8. Luna LG. Manual of Histological Staining Methodes of the Armed Force Institute of Pathology, $3^{\text {rd }}$ ed. New York: McGraw Hill Book Co.; 1968; 21 - 32, 127 - 128.

9. Kass L. Cytometry of Esterase. CRC; 1979; 10: $205-223$.

10. Pohan S. Pewarnaan Sitokimia Pada Lekemia Akut. Usaha Membuat Diagnosis dan Klasifikasi Lebih Tepat untuk Menunjang Pengobatan. [Tesis]. Surabaya: Sekolah Pascasarjana Universitas Airlangga. 1983.

11. Boseila AWA. Identification and Counting of Basophil leucocytes. Stain technology; 1959; 34:335 - 338.

12. Long MW, William N. Immature Megakaryocytes In The Mouse: Morphology and Quantitation by Acethylcholine Esterase Staining. Blood 1981; 58: 1032 - 1039.

13. Undritz E. Sandoz Atlas of Haematology, $2^{\text {nd }}$ ed. Basle, Sandoz LTD; 1974; 9 - 41.

14. Djaldetti M. Hematopoietic Events in Human Embryonic Spleen at Early Gestational Stage. Biol Neonate; 1979; $36: 133$ $-144$.

15. Wickramasinghe SN. Human Bone Marrow. London: Blackwell Scientific Publication; 1975; 61 - 81.

16. Lila IN. Hemopoisis pada Hati Janin Tikus, Sebagai Model Untuk Mepelajari Pola Perkembangan Hemopoisis di Hati Selama Masa Janin dan Neonatus Pada Manusia. [Tesis]. Surabaya: Fakultas Pascasarjana, Universitas Airlangga. 1983.

17. Cohen JJ. Apoptosis. Immunology Today 1993; 14: 126 - 130.

18. Lemura A, tsai M, Ando A, Wershill BK, Galli SJ. The c-kit ligand. Stem Cell Factor, Promotes Mast Cell Survival by Suppressing Apoptosis. American Journal of Pathology 1994; 144: 321 - 328.

19. Mariani AR, Columbaro M, Zauli G, Zamai L, Lucetti F, Gobbi P, Ghibellni D, Falceiri E, Vitale M. Lineage Related Susceptibility of Human Hematopoietic Cell line to Apoptosis. Anat Record; 1999; 254:1 - 6.

20. Gordon LI, Miller WJ, Branda RF, Zanjani ED, Jacob HS. Regulation of Erythroid Colony Formation by Bone Marrow Macrophage. Blood; 1990; 55: 1047 - 1050.

21. Young NS, Alter BP. Aplastic Anemia Acquired and Inherited. Philadelphia: WB Saunders Company; 1994; 32 - 100.

22. Melenhorst JJ, Fibbe WE, Struyk L, van der Elsen PJ, Willemze R, Landegent. Analysis of $t$ cells Clonality in Bone Marrow of Patient with Acquired Aplastic Anaemia. British Journal of Haematology; 1997; 96: 85 - 91.

23. Cole RJ, Paul J. The Effect of Erytropietin on Haem Synthesis In Mouse Yolk Sac And Cultured Foetal Liver Cells. J Embryol exp Morph 1996; 15: 245 - 260. 